Discussion Paper No. 13-040

Labour Market Performance in OECD Countries:

A Comprehensive Empirical Modelling Approach of Institutional Interdependencies

Andreas Sachs and Frauke Schleer

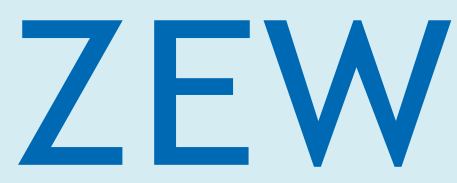

Zentrum für Europäische Wirtschaftsforschung $\mathrm{GmbH}$ Centre for European Economic Research 
Discussion Paper No. 13-040

\title{
Labour Market Performance in OECD Countries: A Comprehensive Empirical Modelling Approach of Institutional Interdependencies
}

\author{
Andreas Sachs and Frauke Schleer \\ Download this ZEW Discussion Paper from our ftp server: \\ http://ftp.zew.de/pub/zew-docs/dp/dp13040.pdf
}

Die Discussion Papers dienen einer möglichst schnellen Verbreitung von neueren Forschungsarbeiten des ZEW. Die Beiträge liegen in alleiniger Verantwortung der Autoren und stellen nicht notwendigerweise die Meinung des ZEW dar.

Discussion Papers are intended to make results of ZEW research promptly available to other economists in order to encourage discussion and suggestions for revisions. The authors are solely responsible for the contents which do not necessarily represent the opinion of the ZEW. 


\section{Non-technical Summary}

The recent economic crisis has resulted in a dramatic deterioration of economic growth and labour market performance in various industrialized countries. There is a widespread view that economies under pressure associated with high unemployment or low employment rates need to change their institutional environment. This needs to happen by conducting structural labour market reforms in order to improve labour market performance by, for instance, facilitating job reallocation processes or increasing labour market flexibility. Nevertheless, some authors argue that an institutional reform which is successful in one country might not be equally successful in another economy. A reform is assumed to depend on the country-specific institutional framework. Despite extensive theoretical and empirical contributions about the link between labour market institutions and labour market performance, evidence on the impact of changes of labour market rigidities on labour market performance which take the country-specific institutional framework and potential institutional interactions into account is still scarce.

This paper contributes to the literature on interdependent institutional labour market effects by analyzing the impact of interdependencies between institutional factors for the evolution of unemployment. We follow the general theoretical model of Belot and van Ours (2004) in order to select institutional factors which are expected to have (interdependent) effects on the labour market. In order to model interactions in an econometrically correct way, we apply an innovative model selection approach to this literature, which is combined with a classical dynamic fixed-effect estimator for a two-way error component model. In doing so, we identify higher-order institutional interdependencies which matter for unemployment for a panel of 26 countries with annual data ranging from 2001 to 2008. In contrast to the previous literature, this paper is the first to focus on the impact of higher-order institutional interactions on unemployment and one of the first to consider a dynamic model specification in the context of institutional interactions. It thereby allows for a more precise and detailed analysis of the impact of interdependencies between different labour market institutions on labour market performance on a cross-country level.

The results suggest that there are substantial qualitative and particularly quantitative differences across countries in the labour market impact of institutional changes for some selected institutional indicators. Hence, the impact of a reform of employment protection, unemployment benefits, labour taxes, bargaining power, and bargaining coordination crucially depends on the country-specific institutional setting. Furthermore, the findings are of considerable importance for the theoretical literature. We provide evidence for the existence of higher-order institutional interdependencies. We further document that especially for changes in employment protection and the unemployment benefit system the impact on unemployment is mixed across countries, thus questioning the relevance of best-practice policies. 


\section{Das Wichtigste in Kürze}

Die Finanz- und Wirtschaftskrise hat zu einem erheblichen Einbruch der Wirtschaftsleistung sowie zu einer Verschlechterung der Arbeitsmarktsituation in einer Reihe von Industrieländern geführt. Oftmals wird diesen Ländern empfohlen, Reformen zur Verbesserung der Rahmenbedingungen auf dem Arbeitsmarkt - Arbeitsmarktinstitutionen - durchzuführen, um etwa die Arbeitslosigkeit zu verringern. Dies können Reformen sein, die Reallokationsprozesse verbessern oder die Flexibilität auf dem Arbeitsmarkt erhöhen. Allerdings wird von einigen Autoren die These vertreten, dass eine institutionelle Reform nicht zwingend den gleichen (positiven) Effekt in verschiedenen Ländern haben muss. Vielmehr hängt der Effekt einer solchen Reform vom jeweiligen länderspezifischen institutionellen Umfeld ab. Trotz zahlreicher theoretischer sowie empirischer Beiträge zur Bedeutung von Arbeitsmarktinstitutionen für den Arbeitsmarkt sind allerdings Erkenntnisse über die Wirkungsweise von institutionellen Veränderungen in Abhängigkeit vom länderspezifischen institutionellen Umfeld rar.

In dieser Studie wird die Bedeutung von Wechselwirkungen zwischen verschiedenen arbeitsmarktinstitutionellen Faktoren für die Entwicklung der Arbeitslosigkeit untersucht. Dabei bauen wir auf dem allgemeinen theoretischen Modell von Belot und van Ours (2004) auf, um diejenigen institutionellen Faktoren zu identifizieren, die theoretisch eine solche Wechselwirkung aufweisen können. Um Interaktionen ökonometrisch adäquat abbilden zu können, wenden wir eine in diesem Forschungsfeld innovative Modellselektionsmethode an, die mit einem klassischen dynamischen Schätzer kombiniert wird. Auf diese Weise werden für ein Panel mit jährlichen Beobachtungen von 2001 bis 2008 für 26 Ländern institutionelle Interaktionen höherer Ordnung empirisch identifiziert, die für die Entwicklung der Arbeitslosigkeit von Bedeutung sind. Im Gegensatz zur bisherigen Literatur fokussiert der Beitrag auf die Arbeitsmarkteffekte institutioneller Interaktionen höherer Ordnung, d.h. einer Wechselwirkung zwischen mehr als zwei institutionellen Faktoren. Zudem ist die Studie eine der ersten, die ein dynamisches Modell für die Identifikation von institutionellen Wechselwirkungen heranzieht, wodurch zum einen Probleme der Modellspezifikation abgemildert werden und zum anderen kurzfristige Anpassungsreaktionen von Änderungen des institutionellen Umfelds abgebildet werden können. Dadurch gelingt es, ein präziseres und detaillierteres Bild von Wechselwirkungen zwischen institutionellen Faktoren und deren Bedeutung für den Arbeitsmarkt auf makroökonomischer Ebene zu zeichnen.

Die Ergebnisse legen nahe, dass vor allem quantitativ, aber auch qualitativ erhebliche Unterschiede in den Arbeitsmarkteffekten durch bestimmte institutionelle Änderungen zwischen den untersuchten Industrieländern bestehen. Dementsprechend hängt die Wirkung einer Reform des Kündigungsschutzes, der Arbeitslosenunterstützung, der Arbeitsbesteuerung, der Koordination der Lohnverhandlungen sowie der Lohnverhandlungsmacht entscheidend vom länderspezifischen institutionellen Umfeld ab. Dies stellt auch die Direktive einer "best-practice" 
Politik in Frage. Der Hinweis auf die Existenz von Interaktionen höherer Ordnung ist ebenfalls von erheblicher Bedeutung für die theoretische Literatur, die sich mit der Modellierung der Wirkung spezifischer Reformmaßnahmen beschäftigt. Schließlich deuten die Resultate darauf hin, dass insbesondere Änderungen des Systems der Arbeitslosenunterstützung sowie des Kündigungsschutzes Arbeitsmarkteffekte zeigen, die sowohl quantitativ als auch qualitativ zwischen den Ländern stark differieren. 


\title{
Labour market performance in OECD countries: A comprehensive empirical modelling approach of institutional interdependencies*
}

\author{
Andreas Sachs ${ }^{\dagger}$ Frauke Schleer ${ }^{\ddagger}$
}

July 1, 2013

\begin{abstract}
Reducing institutional rigidities in product and labour markets is key to lowering unemployment. The impact of such labour and product market reforms, however, depends crucially on the country-specific regulatory framework. In this paper, we estimate the country-specific impact of changes in six categories of institutional regulation conditional on the country-specific regulatory environment for a dynamic panel of 26 OECD countries. We overcome existing problems of modelling a large set of institutional interdependencies by applying a model selection approach which is innovative within this literature. In doing so, we provide evidence for the existence of higher-order institutional interdependencies. We further document that especially for changes in employment protection and the unemployment benefit system the impact on unemployment is mixed across countries, thus questioning the relevance of best-practice policies.
\end{abstract}

JEL classification: C33, E02, E24

Keywords: Labour market institution, institutional interdependencies, model selection, heuristic optimization

*The research leading to these results has received funding from the European Community's Seventh Framework Programme FP7/2007-2013 under grant agreement no. 290647. For further information on projects of the authors see www.zew.de/staff_ass and www.zew.de/staff_fsl as well as the ZEWannual report on www.zew.de/en. We are grateful to Leonhard Brinster, Lisardo Erman and Daniel Maas for excellent research assistance. We are especially indebted to Peter Winker for helpful comments and suggestions. We also thank Jan Hogrefe for valuable comments. All remaining errors are our own.

${ }^{\dagger}$ Corresponding author, Centre for European Economic Research (ZEW), P.O. Box 103443, D-68161 Mannheim, Germany, Phone: +49/621/1235-145, Fax: +49/621/1235-223, E-mail: sachs@zew.de

${ }_{\ddagger}^{\ddagger}$ Centre for European Economic Research (ZEW), P.O. Box 103443, D-68161 Mannheim, Germany, Email: schleer@zew.de 


\section{Introduction}

The recent economic crisis has resulted in a dramatic deterioration of economic growth and labour market performance in various industrialized countries. There is a widespread view that economies under pressure associated with high unemployment or low employment rates need to change their institutional environment. This needs to happen by conducting structural labour market reforms in order to improve labour market performance by, for instance, facilitating job reallocation processes or increasing labour market flexibility. Despite extensive theoretical and empirical contributions about the link between labour market institutions and labour market performance, evidence on the impact of labour market rigidities on labour market performance which take the country-specific institutional framework and potential institutional interactions into account is still scarce.

Theoretical and empirical contributions suggest that an institutional reform which is successful in one country might not be equally successful in another economy $\left.\right|^{1}$ An explanation could be that institutions do not work in isolation. This is in line with the rising doubt of best practice solutions across EU member states. The impact of a reform which changes the level of an institutional rigidity is likely to depend on the entire institutional environment. The Danish flexicurity system is a good example. Andersen and Svarer (2007) point out that the relatively low unemployment rate in Denmark since mid-1990 is due to a labour market reform which complements pre-existing low employment protection and high replacement rates with a newly introduced active labour market policy. Caused by this reform, labour is allocated more efficiently through the combination of low employment protection, a suitable safety net (high replacement rates) and adequate activation measures to avoid the loss of job-specific networks and human capital.

According to this, labour market institutions have to be matched to each other to work well. While reducing employment protection is likely to result in lower unemployment in countries characterized by a generous unemployment benefit system and pronounced active labour market policies, the reform could have no or even a contradictory effect in countries with low unemployment benefit levels and/or less efforts to bring people back to work. This example again highlights the importance of interdependent institutional effects on a country's labour market performance.

The implementation of a European semester of policy coordination by the European Union indicates that the issue of country-specific institutional settings is highly relevant from a policy perspective. The European Semester is an EU-level policy coordination tool which serves to ensure that EU members reach the goals of the Europe 2020 Strategy by boosting growth and employment in order to initiate convergence in competitiveness in Europe. The recent economic

${ }^{1}$ See Coe and Snower $(1997)$ and Belot and van Ours (2004) for a theoretical treatment, and Bassanini and Duval (2009) and Sachs (2011) for an empirical investigation of this topic. 
crisis led some EU member countries losing track of these goals. Increasing unemployment rates, growing budget deficits and low GDP growth rates provoke the need for substantial labour market adjustments in these countries to both improve labour market performance and to reduce the governmental financial burden for the social security system, which are both essential for improving competitiveness. However, the implementation of required adjustments is often prevented by missing political support or lack of knowledge of which adjustments to perform. The EU tries to overcome these problems by providing supranational policy guidance which includes recommendations for institutional adjustments in the labour market.

Such recommendations for country-specific institutional adjustments should have a sound and reliable scientific basis in order to avoid futile or even detrimental institutional effects, and to facilitate coordination from the perspective of the European Union. Microeconomic studies are well-suited to provide evidence on institutional effects for specific groups of workers or firms. However, such studies do not calculate aggregate institutional effects, that is, for the whole economy. In contrast, macroeconomic approaches are able to do so. So far, most empirical macroeconomic studies do not adequately take interdependencies between institutions into account but focus on isolated institutional effects or on few subjectively selected interdependencies, instead. Theoretical contributions either focus on a single specific interdependency or deal with a broad but imprecise characterization of interactions. Such limited theoretical guidance for empirical model specification in combination with an insufficient number of observations is the main reason for many studies disregarding institutional interactions from a macroeconomic perspective.

This paper aims at closing this gap by introducing model selection methods which are innovative within this literature, namely heuristic optimization procedures, in order to comprehensively take the impact of institutional interdependencies on labour market performance into account. To be specific, we follow the general theoretical model of Belot and van Ours (2004) in order to select institutional factors which are expected to have (interdependent) effects on the labour market. We then specify a dynamic empirical panel model for 26 OECD countries which explains unemployment, our preferred measure of labour market performance, by institutions, interdependencies between institutions, and a set of control factors. This model can then be used as a basis for the identification of institutional effects on unemployment. There are two main advantages of this approach over the previous literature. First, the potential impact of an institutional adjustment on the labour market can be evaluated depending on the countryspecific institutional parameterization. Second, it allows for higher-order interactions without restricting the model space on subjective grounds.

The results suggest that there are substantial differences across countries in the labour market impact of institutional changes for nearly all selected institutional indicators. Hence, the impact of a reform of employment protection, unemployment benefits, labour taxes, bargaining power, and bargaining coordination crucially depends on the country-specific institutional set- 
ting. Furthermore, the findings are of considerable importance for the theoretical literature. We provide evidence for the existence of higher-order institutional interdependencies. We further document that especially for changes in employment protection and the unemployment benefit system the impact on unemployment is mixed across countries, thus questioning the relevance of best-practice policies.

The paper is organized as follows. Chapter 2 provides an overview of existing approaches to theoretically identify and empirically estimate labour market effects of interdependent labour market institutions. Chapter 3 deals with the empirical model specification employed in this paper while chapter 4 introduces the corresponding model selection techniques. Data issues are described in chapter 5 , results of the model selection approach are presented in chapter 6 , and chapter 7 concludes.

\section{Literature review}

Over the last twenty years, a plethora of empirical contributions sought to identify the direct impact of institutions on unemployment or employment rates. Earlier studies come to the conclusion that rigid labour markets through, for instance, high employment protection or generous unemployment benefit systems are responsible for weak labour market performance.2 More recent studies benefit a lot from developments in data quality and estimation methods which improved the reliability of the results and questioned the orthodox view that rigid institutions lead to undesirable labour market outcomes.3

Yet, the aforementioned studies ignore the institutional environment, hence, the countryspecific institutional set-up, of a country as a whole. As Belot and van Ours $(2004)$ and Coe and Snower (1997) argue, the same institutional reform need not necessarily have the same labour market impact in different countries. A reform might have a different impact depending on other country-specific institutional aspects. This idea of institutional interdependencies has been taken up in some empirical studies differing in terms of which interdependencies are included. Belot and van Ours (2004) specify a model explaining unemployment which considers three interactions - between labour taxes and unemployment benefits, employment protection and bargaining centralization, and union density and bargaining centralization. The findings indicate that institutional interactions are relevant for explaining unemployment in OECD countries. Similar empirical approaches, albeit with a different and limited sets of bivariate interactions, are chosen by Nickell et al. (2005) and Baccaro and Rei (2007). Bassanini and Duval (2009) apply a more comprehensive approach. They emphasize that subjectively selecting some interactions can result in considerably biased estimates due to an omitted variable bias caused

\footnotetext{
${ }^{2}$ See, inter alia, OECD (1994), Scarpetta (1996), Elmeskov et al. (1998), Blanchard and Wolfers (2000), IMF (2003).

${ }_{3}^{3}$ See Howell et al. (2007), Baccaro and Rei (2007), Bassanini and Duval (2009) and Sachs (2012).
} 
by the exclusion of further potentially relevant interactions. By estimating all possible bivariate interactions between six institutional factors jointly, and by further applying an instrumental variable estimator, they take an important step forward by reducing the risk of an omitted variable bias. Although almost no interaction appears relevant, the authors emphasize that the findings do not imply that interactions are irrelevant, but that a small sample size might prevent more precise estimates. The problem of being faced with an insufficient number of observations is tackled in Sachs (2011) by the application of a Bayesian model averaging approach. Bivariate interactions between 14 institutional indicators are constructed and their impact on unemployment is estimated in a static model set-up. The model averaging approach enables the robust estimation despite a limited number of observations and a potentially large set of relevant explanatory factors. The outcomes highlight the importance of institutional interdependencies for a country's labour market performance in the long-run. 22 bivariate interaction terms are robustly linked to unemployment, and nearly all considered institutional indicators turn out to be relevant interaction partners. However, neither higher-order interactions nor a dynamic specification are considered in that contribution.

Instead of constructing interaction terms between individual institutions, Bassanini and Duval (2009) further analyse the interaction between a particular institution and the countryspecific institutional framework as a whole. This is done by estimating a specification where the latter is defined by the sum of direct unemployment effects of institutions. Indeed, results produced with such a model suggest that the impact of an institutional change on unemployment depends on the aggregate institutional setting. The less rigid the overall institutional framework, the more successful are deregulating institutional reforms. According to this, institutions seem to be complementary, i.e. jointly reducing regulation is successful; a hypothesis which is also advanced by Coe and Snower (1997). While this approach is clearly appealing it suffers from combining already highly aggregated individual institutional indicators even further to an indicator of a country's institutional setting. If there is considerable heterogeneity in institutions, this method might neglect relevant institutional information. Furthermore, Sachs (2011) does not find a general tendency towards complementary institutions. Therefore, we see the approach of Bassanini and Duval (2009) as a first step we can build on by applying a more structural approach.

While both aforementioned studies take a large set of bivariate interactions into account, higher-order interactions are completely neglected. Recalling the example of the successful Danish flexicurity system such higher-order interactions between more than two institutions can be highly relevant and existing empirical models including merely bivariate interactions might provide misleading evidence. But higher-order interactions also matter from a technical point of view. According to Braumoeller (2004), once a model with two interactions $X_{1} X_{2}$ and $X_{2} X_{3}$ is specified, the interactions between $X_{2} X_{3}$ and $X_{1} X_{2} X_{3}$ must be taken into account, as well $4^{4}$

\footnotetext{
${ }^{4}$ In this case, $X_{1}$ and $X_{2}$ are called the constitutive terms of the interaction term $X_{1} X_{2}$.
} 
Neglecting the trivariate interaction term is equivalent to assuming that the coefficients of the bivariate interaction terms $X_{1} X_{2}$ and $X_{2} X_{3}$ measure the impact on unemployment given that the third variable is zero. Hence, $X_{1} X_{2}$ gives the impact of $X_{1}$ on unemployment conditional on the level of $X_{2}$ and given that $X_{3}=0$. If this assumption does not hold and the trivariate interaction is a significant explanatory factor, estimates are biased. It is therefore necessary to additionally include $X_{1} X_{2} X_{3}$ irrespective of its economic relevance but for pure technical reasons.

\section{Empirical Model Specification}

Our study seeks to first identify relevant institutional interactions for a given set of institutional factors and second to determine the country-specific marginal effects of institutional changes on the labour market by taking the country-specific institutional environment into account. The model selection approach applied in this study is used to generate reliable empirical results despite limited theoretical guidance. Yet, some theoretical considerations are necessary to define the set of potentially interacting institutions. To do so, the right-to-manage model of Belot and van Ours (2004) is taken as the theoretical basis for the following empirical exercise. In this model, the unemployment benefit system, the labour tax system, employment protection, bargaining coordination, union bargaining power, and product market regulation can theoretically have an interdependent impact in the labour market by affecting the levels and the elasticities of labour supply and demand. More precisely, the labour market impact of a reform that changes the level and/or the elasticity of labour supply depend on the level and the elasticity of labour demand and vice versa. Hence, the labour market effect of a change of an institution can depend on one or more other institutions. Overall, considering the six institutional factors of Belot and van Ours (2004) adds up to a set of 63 variables (six individual institutional indicators plus 57 bivariate and higher-order interaction terms) which might be relevant explanatory factors.

Most econometric studies focusing on the link between labour market performance and institutions use static models. More recently, dynamic models gained importance in this literature. While Fiori et al. (2012) promote a dynamic specification on the grounds of a missing cointegrating relationship between unemployment and institutions; we use a dynamic model for the following reason. The main goal of this paper is to provide an empirical basis for recommendations in terms of institutional adjustments. As pointed out by Nickell et al. (2005) unemployment is probably exposed to some degree of endogenous persistence. This means that explanatory factors might have an influence on unemployment which lasts longer than one year. A static model would not be able to adequately capture this kind of influence and reform recommendations would be inadequate. 
Accordingly, the model explaining labour market performance reads

$$
Y=X \beta+Z \theta+C \gamma+U
$$

The dependent variable $Y$ is given by the unemployment rate and is a vector of size $N T \times 1$, $X$ is a $N T \times K$ matrix containing institutional factors as well as the lagged dependent variable, $Z$ is a $N T \times G$ matrix of bivariate and higher-order interactions between the six variables describing specific institutional settings, $C$ is a $N T \times L$ matrix of control variables, and $\beta, \theta$ and $\gamma$ are the corresponding coefficient vectors of the explanatory variables.

The inclusion of the lagged dependent variable entails that the persistence of the unemployment rate can be adequately captured. However, marginal institutional effects now can only explain a short-term movement of the unemployment rate, since long-term adjustments are captured by the lagged dependent variable. This approach is sometimes criticized for leaving very little variation over time to the explanatory variables. In other words, a large part of the variation in unemployment is explained by lagged unemployment. If one is explicitly interested in the long-term effects of institutions in unemployment, it could be preferable to specify a static model. If one, however, is interested in finding a model which explains short-term movements in unemployment properly, a dynamic specification is preferable. The same rationale serves for taking time- and country-specific fixed effects into account. Accordingly, the error term is specified as

$$
u_{i, t}=\alpha_{i}+\lambda_{t}+\nu_{i, t}
$$

Here, $\alpha_{i}$ is the country-specific effect which captures time-invariant unobservable determinants of unemployment. Such unobservables could comprise of cultural or social differences across countries like the attitude to work. $\lambda_{t}$ is the time-specific effect which takes global events affecting all countries equally into account. An example for this might be a global recession which impacts on the labour markets of all countries.

Estimating a dynamic two-way error component panel data model with fixed effects can deliver biased and inconsistent estimates since the lagged dependent variable is correlated with $\alpha_{i}$ which is part of the error term (see Baltagi (2003)). Especially for a short time-series, the error could be large. A solution to this is the application of the Arellano and Bond (1991) difference GMM estimator. This estimator transforms the model in differences and uses lagged levels of the dependent variable as instruments. While this estimator performs well when the instruments are appropriate, it is biased for weak instruments. Thus, Blundell and Bond (1998) suggested additional moment restrictions by setting up a system GMM estimator. Here, the system consists of the model equation in differences with lagged levels as instruments, and the model equation in levels with lagged differences as instruments. This estimator is theoretically particularly suitable for persistent dependent variables as it is in our set-up. However, while 
the system GMM estimator is theoretically superior to a fixed effects estimator, the practical implementation is often hampered by the invalidity of the instrument matrix for both the difference and the level equation, especially when the country- and time dimensions are small and the time series are persistent (see Bun and Windmeijer (2010)). Hence, we first apply a simple fixed effects estimator and subsequently check the findings by applying the model selection method to the system GMM estimator. For the fixed effects estimator, we perform a recently developed LM-test for serial correlation which is especially adequate for panels with small T (Born and Breitung, 2013). A penalty is added to the target function of a specific model if serial correlation is detected. In doing so, we avoid to select models which are mis-specified indicated by serially correlated error terms.

Validation of the system GMM estimator requires the verification of the following three assumptions: validity of the instruments, covariance-stationarity of the endogenous variable, and no second order serial correlation in the residuals. The first assumption is tested by the Sargan test of overidentifying restrictions. The second assumption implies that the coefficient of the lagged dependent variable should converge to a steady-state and consequently be smaller than unity (Roodman, 2009). This can be tested with a Difference Sargan test of the full instrument set against the instrument set of the first-differenced GMM estimator (Blundell and Bond, 2000). Finally, there should be no second order serial correlation in the residuals. This assumption can be tested with the Arellano-Bond serial correlation test (Arellano and Bond, 1991).5 In principle, each of the three tests should be applied to each panel model that is estimated by system GMM.

\section{Selecting interactions using heuristic optimization tech- niques}

\subsection{Optimization Problem}

As theory offers no explicit guidance which kind of institutional interdependencies are crucial for the well-functioning of the labour market, we seek to identify relevant institutional interactions empirically. This should provide useful insights for theoretical model-builders to incorporate institutions and their interactions. Besides the ambiguity of the theory, a key methodological problem in model selection within a multiple regression model when the relevant variables are not known a priori is the trade-off between consistency and efficiency. Taking a large number

\footnotetext{
${ }^{5}$ For the sake of an efficient estimation one can apply the second-step weighting matrix which is based on the residuals of the first-step estimation. In this case the Sargan test can be replaced by the Hansen $J$ test which is robust to heteroscedasticity but vulnerable to instrument proliferation (Roodman, 2009). In this case, Roodman suggests a "collapsing" of the instrument matrix. Here we report first-step estimates, since the second-step weighting matrix seems to be poorly estimated because of weakly changing regressors, resulting into unstable second-step estimates.
} 
of regressors into account increases the variance, whereas including too few variables leads to inconsistent estimates. In our application, allowing for all possible interactions of $K=6$ institutional variables leaves us with $2^{57}$ models to be estimated including the individual, noninteracting variables as well as the control factors. It becomes infeasible to estimate all potential combinations even when efficient methods are used (Gatu et al., 2008). Being faced with this problem, there exist several approaches for finding an efficient way to obtain an optimal outcome by estimating only a subset of all potential models within the model selection literature.

Following the (standard) model selection techniques of Leamer (1983) and Sala-I-Martin (1997), Fernandez et al. (2001) propose Bayesian Model Averaging as a new model selection technique. In general, these model averaging approaches are used to identify robust and significant explanatory variables from a large set of potentially relevant explanatory factors. Thus, model averaging approaches are linked to model selection by providing a rationale for selecting the set of explanatory factors. This method uses inclusion probabilities of individual variables to approach the true model ${ }^{6}$ Alternatively, Krolzig and Hendry (2001) and Hoover and Perez (2004) suggest a general-to-specific approach based on statistical tests belonging to the frequentist strand. Hendry and Krolzig (2004) provide a programme PcGets for model selection purposes which relies on a general-to-specific procedure and searches along multiple paths. Perez-Amaral et al. (2003) provide another type of model selection tool - a network approach - called RETINA. In our study, we focus on optimization methods which efficiently and objectively search through the model space in order to avoid sequential procedures in which subjective elements prevail. In particular, we apply heuristic optimization techniques as advocated by e.g. Savin and Winker (2012), Acosta-González and Fernández-Rodríguez (2007) and Kapetanios (2007). These are able to deal with non-smooth, discrete optimization problems.

Recently, Acosta-González and Fernández-Rodríguez (2007), Kapetanios (2007) and Savin and Winker (2012) have shown that heuristic optimization techniques based on information criteria as objective function deliver promising results in selecting regressors in different model selection set-ups of multiple regression models.7 Kapetanios (2007) documents an outperformance of Simulated Annealing (SA) and Genetic Algorithms (GA) as two classical heuristic methods over PcGets. The closest to our approach is the model selection set-up by Savin and Winker (2012) who apply heuristics to a (dynamic) panel model and identify a genetic algorithm as being the best model selection strategy for this type of model. Hence, we apply a genetic algorithm to select relevant institutional interactions.

An alternative approach to deal with too many potential regressors is using factor augmented regressions (see, for instance, Bai and $\mathrm{Ng}(2006)$ ). However, for our application, linear

\footnotetext{
${ }^{6}$ We do not pursue a Bayesian model selection approach which strongly relies on postulation of priors. In our application, we do not have any theoretical guidance for the prior specification of the interaction terms. Second, Kapetanios (2007) shows that heuristic optimization methods, particularly simulated annealing, are preferable over the $\mathrm{MC}^{3}$ algorithm used by the Bayesian approach.

${ }^{7}$ Winker $(1995,2000)$ and Winker and Maringer (2006) already applied heuristic methods for lag selection to overcome the curse of dimensionality within multivariate VAR models.
} 
factors might not be adequate, as they could hardly cover the higher order effects we are interested in. Moreover, the variables representing institutions are not highly correlated (see Appendix table 6) and hence, we might lose information by aggregating the data even further.

\subsection{Model selection technique}

Let us consider our empirical model explaining unemployment:

$$
Y=X \delta+Z^{\text {cand }} \varphi \theta+C \gamma+U
$$

where $Z^{\text {cand }}$ denotes all candidate regression variables, that is all interactions up to order six. $\varphi$ is a $G \times G$ matrix of zero and ones on the diagonal, depending on which interactions are selected. As a constraint the levels of the institutional variables contained in $X$ as well as the control factors $C$ are forced to be included in each selected model. Brambor et al. (2006) point out that even if a constitutive term $\left(X_{1} X_{2}, X_{1} X_{3}, X_{2} X_{3}, X_{1}, X_{2}\right.$ and $X_{3}$ are the constitutive terms of the interaction $X_{1} X_{2} X_{3}$ ) of an interaction is insignificant in statistical terms (applying the usual t-test) this is not sufficient to leave out this constitutive term from the equation. According to them, there are two conditions which should be fulfilled before a constitutive term can be left out. First, "...the analyst should estimate the fully specified model [...] and find that the [coefficient of the constitutive term] is zero" (page 69). Second, the researcher "must have a strong theoretical expectation that the omitted variable [...] has no effect on the dependent variable in the absence of the other modifying variable..." (page 68). The first condition is taken into account by allowing all constitutive terms to be included in the model, a priori. Since theory neither provides arguments for the exclusion nor for the inclusion of specific constitutive interaction terms, we then exclude constitutive terms on the basis of their particular contribution to the model fit measured by the Bayesian information criterion.

In line with Hendry and Krolzig (2004) and Acosta-González and Fernández-Rodríguez (2007), we checked the general unrestricted model (GUM) for validity by assessing our model set-up carefully. As long as theoretical, data-measurement, and model specification considerations are conducted appropriately the econometric set-up is not prone to the criticism of data-mining (Hendry and Krolzig, 2004). We tackle these issues thoroughly. We select the potentially interacting institutional variables by taking the theoretical model of Belot and van Ours (2004) as basis. Unfortunately, the theoretical literature is not particularly detailed about the link between unemployment and institutional interactions. Hence, we stick to the variables for which the selection is theoretically justified. Second, we use recently published panel data of institutional indicators which is superior to previously used data in order to have a reliable data basis. Finally, the model specification is evaluated either by performing tests of the final model or by directly incorporating the test decisions into the algorithm, depending on the specific 
estimator.

Based on an objective function, we seek to identify the relevant institutional variables. We choose an information criterion as loss function in order to derive a high model fit by simultaneously penalizing for overparametrization. As the Bayesian Information Criterion (BIC) is consistent and seems to deliver superior results in model selection as pointed out by Kapetanios (2007) and Savin and Winker (2012), we select BIC as our target function. To avoid model misspecifications, we add a penalty to the objective function if the selected model has serially correlated errors based on the test developed by Born and Breitung (2013). The null is no serial correlation of order one. The objective function looks as follows:

$$
f=\left(\ln \left(\hat{\sigma}^{2}\right)+k \ln (N T) / N T\right)(1+\text { penalty })
$$

where $k$ denotes the number of estimated parameter. The penalty applies only if there is serial correlation in the errors:

$$
\text { penalty }= \begin{cases}0 & \text { if } p \text {-value }>0.05 \\ 1 / \mathrm{p} \text {-value } & \text { if } \mathrm{p} \text {-value } \leq 0.05\end{cases}
$$

In the following, the genetic algorithm is presented in more detail 8 The heuristic optimization methods are mostly designed in line with the suggestions of Savin and Winker (2012) for dynamic panel model selection. Genetic algorithms (GA) update the whole set of solutions simultaneously (see also table 1 for a pseudocode). They rely on the principle of replicating the evolutionary process such that superior model set-ups have a higher chance to survive. To initialize the algorithm, we select an initial population $(K)$ of 500 initial solutions as advocated by Savin and Winker (2012) $9^{9}$ The members of the population are called chromosomes $(\varphi)$ which are associated with randomly generated binary strings (genes) representing the model structure. For all initial solutions we perform an estimation, calculate the information criterion and report the elitist (=best among all candidate solutions).

After the initialization, the generations $\left(G_{\max },{ }^{10}\right.$ predefined number $)$ start by taking the best half of the originally generated solution (parents, $K^{\prime}$ ). First of all, those are directly transferred to the new population and second, they are used to generate further solutions (children). This works as follows. Based on 100 randomly selected pairs of parents, 200 children (=new model structures) are formed by crossing them over. Moreover, the forty best parents - chromosomes

\footnotetext{
${ }^{8} \mathrm{We}$ also checked local search heuristics like the Threshold Accepting (TA) algorithm as model selection techniques as well. Since TA delivers worse results in terms of the information criterion, we stick to the genetic algorithm (see chapter results). This finding - the superiority of the genetic algorithm within this type of model set-up - is in line with Savin and Winker (2012). More details of TA can be found in the appendix.

${ }^{9}$ The size of the initial set of the generated model structure (population) should be sufficiently large to allow for diversification such that a broad range of the search space is covered. Yet, it should not be too large to search efficiently through the search space finding the best solution.

${ }^{10}$ The number of generations $\left(G_{\max }\right)$ amounts to $500(250,000$ iterations divided by population size $(p=500)$ for each restart. We set the number of restarts to 10 .
} 
with best value of objective function - generate 40 children. This leaves us with overall 240 $(C)$ solutions generated by the uniform crossover mechanism. To get the 10 further solutions, we use the ten best solutions $\left(K^{*}\right)$ and change them at one random gene. Having formed a new population, the information criterion is calculated based on the estimation outcome. After sorting the new population by their objective function value, a random mutation, which refers to a small, if any, change of the model structure, is done to prevent the algorithm from a trap in a local minimum. This mutation is applied to the new population except the ten best model structures $\left(K^{* *}\right)$ and the ten children generated from $K^{*}$ (elitist). Thereby, eight random elements (genes) are changed with probability 0.5 over all elements of the population described before. Again, at this step the elitist value and the associated model structure are stored. The algorithm runs either a predefined number of generations $\left(G_{\max }\right)$ or stops if all elements of the population have converged to be identical; implying that the algorithm has converged to an optimum.

Table 1: Pseudocode for Genetic Algorithm

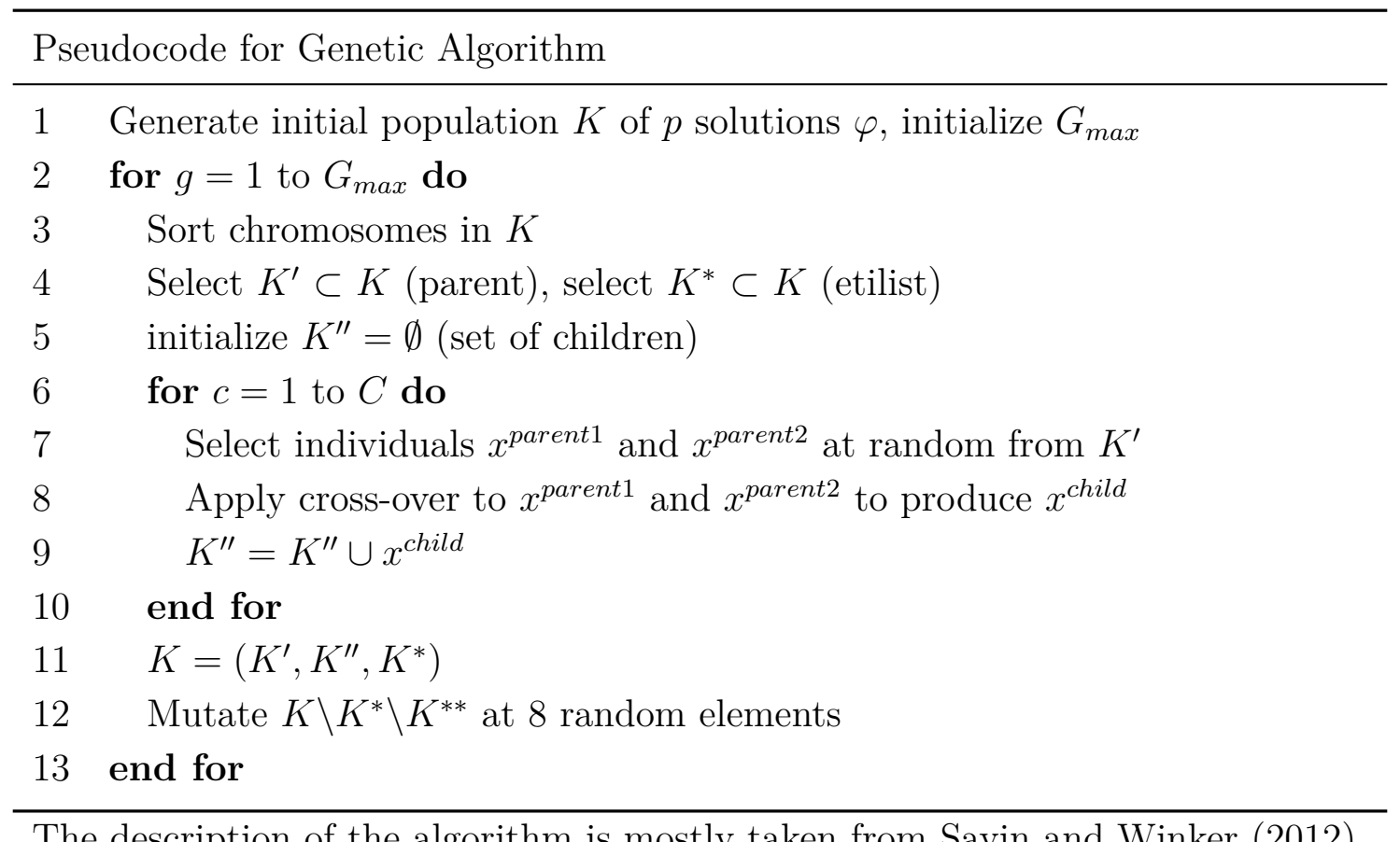

\section{Data}

The analysis is based on a balanced data set with annual observations for 26 OECD countries from 2001 to 2008. It holds a set of six institutional variables, 57 institutional interactions, and four control factors. Summary statistics for the variables are given in the Annex in table 6 . The estimation of a model with more than one interaction term is often blamed to suffer from multicollinearity. This is especially a risk if the constitutive terms, that is, the six institutional 
indicators, are highly correlated. For our data sample, multicollinearity issues seem to play a minor role as 0.5 is the strongest correlation observed between two individual institutions; most of of them are closer to zero or even negative. The complete correlation matrix is given in the Annex in table 7. In terms of fixed-effects estimation, the problem of imprecise estimates through rarely changing explanatory factors over time is alleviated. In principle, the fixed effects absorb all time-invariant influences on the dependent variable. Estimating the impact of rarely changing variables on unemployment is difficult in such a set-up. However, while employment protection or bargaining coordination does not change much over time, interacting rarely changing variables provides substantial exogenous variation over time and enables the precise identification of interaction term coefficients.

\subsection{Labour market performance}

Several indicators like the unemployment rate, the employment rate, joblessness, or inactivity can serve as a proxy for labour market performance. The most prominent indicator in econometric studies has been the unemployment rate. Nickell and Layard (1999) argue that this is the best measure for labour market performance "because it is probably the least voluntary". The lower the unemployment rate the less persons are actively searching for a job and, consequently, the better the state of the labour market. However, measuring unemployment also has some drawbacks. It is difficult to compare unemployment rates across countries since national concepts might differ. A country could lower its unemployment rate by job creation schemes. In order to tackle this problem, the OECD constructed harmonized unemployment rates calculated according to international standards. These series are better suited for international comparisons of labour market performance than pure national numbers. Thus, our dependent variable is the harmonized unemployment rate provided by the OECD 11

\subsection{Institutional variables}

On basis of the theoretical model of Belot and van Ours (2004), six institutional factors are supposed to show an interdependent impact on unemployment.

The net replacement rate for an average production worker averaged over different family situations is used as an indicator for the generosity of the unemployment benefit system. It measures the unemployment benefits as a percentage of the last job wage. Note that this indicator has recently been published by the OECD and represents a substantial improvement over the gross replacement rates. This latter factor has been used in nearly all studies focusing on institutions. While gross replacement rates relate income during unemployment to the gross last job wage, net replacement rates refer to net last job wages. Comparisons both across

\footnotetext{
${ }^{11}$ For Switzerland, no annual harmonized unemployment rate is available. However, the OECD reports the unemployment rate for the second quarter of a year. This value is taken to approximate the annual unemployment rate for Switzerland.
} 
countries as well as over time are much more reliable with the net indicator since differences or changes in the tax system do not have an effect on the replacement rate. Interestingly, Howell and Rehm (2009) report only a small correlation between the OECD gross and net replacement rates. This emphasizes the importance of considering the net measure to take the unemployment benefit system adequately into account.

The labour tax system is approximated by the tax wedge delivered by the OECD. This indicator measures the amount of income taxes and social security contributions paid by the employee, and payroll taxes and social security contributions paid by the employer, as well as family benefits received by the employee for an average production worker for different family situations as a percentage of the total labour compensation.

Employment protection can be well described by an OECD indicator which comprises information from different dimensions of employment protection. The values of this indicator which is a metric summary variable of various subfields of protection can theoretically lie within the range from 1 to 6 , and are increasing in the degree of protection.

The degree of coordination between employers and employees in the wage bargaining process gives the level of bargaining coordination. It can take the values 1 to 5 , where higher values indicate a higher degree of coordination. A value of 5 means economy-wide bargaining while a value of 1 expresses fragmented bargaining which takes place mostly at the company level. Note that this measure includes both the formal and the informal dimension of coordination. Soskice (1990) argues that bargaining centralization only measures the level at which bargaining takes place. Bargaining coordination, in turn, is a more general concept which comprises, besides bargaining centralization, of other forms of centralization. Even if a country exhibits rather decentralized bargaining, coordination could be high with a considerable impact on the wage bargaining process. Soskice (1990) takes Switzerland and Japan, both with highly decentralized, company-level bargaining, as examples to illustrate such distinct centralization and coordination measures. Coordination comes in through higher-level employer organizations in Switzerland, and informal wage cartels in Japan.

For union bargaining power, the union density, which measures the share of employees organized in unions, is provided by Visser (2011), and is our preferred indicator. Recently the union coverage has gained importance as an indicator for union bargaining power since it covers not only all employees organized in unions but all employees affected by union wage agreements. This indicator cannot be considered here due to inadequate coverage over time.

An indicator for product market regulation is available from the Fraser Institute which publishes the Economic Freedom of the World Index (Gwartney et al., 2012). This measure measure lies in the range from 1 to 10 and comprises information on business regulations stemming from seven sources: price controls, administrative requirements, bureaucracy costs, starting a business, extra payments/bribes/favoritism, licensing restrictions, and cost of tax compliance. In the original data source, the value is decreasing in the degree of regulation. In 
order to ensure that deregulation is linked to decreasing indicator values for the institutional factors we multiply the product market regulation value with -1 .

\subsection{Control factors}

Similar to Fiori et al. (2012), the output gap, which gives the percentage deviation of the cyclical component from trend growth, is used to control for cyclical fluctuations in (un)employment. Trend growth is calculated on the basis of a production function. Following Amable et al. (2011), three additional factors, the first time difference of the real exchange rate, the structural trade balance, and the average labour productivity are used as control factors. The data series are provided by the OECD via its Economic Outlook.

\section{Results}

The basic estimation approach is to apply the genetic algorithm as the preferred model selection tool in combination with a simple dynamic fixed effects estimator ${ }^{12}$ Theoretically, system GMM is superior but might be plagued by difficulties to determine the optimal instrumental variable structure. We later run the model selection approach with the system GMM estimator as a robustness check. While the statistical identification of relevant interaction terms can be reliably done with the model selection approach applied in this paper, a further step is needed to provide an economic interpretation of this finding. This is done by calculating marginal effects of the institutional factors. Assume the following model where the dependent variable $Y$ is explained by three factors $X_{1}, X_{2}$ and $X_{3}$, and all possible interactions between these factors:

$$
Y=\beta_{1} X_{1}+\beta_{2} X_{2}+\beta_{3} X_{3}+\beta_{4} X_{1} X_{2}+\beta_{5} X_{1} X_{3}+\beta_{6} X_{2} X_{3}+\beta_{7} X_{1} X_{2} X_{3}+\epsilon
$$

The marginal effect of a factor $X_{1}$ on $Y$ is then calculated as the first derivative of $Y$ with respect to $X_{1}$

$$
\frac{\delta Y}{\delta X_{1}}=\beta_{1}+\beta_{4} X_{2}+\beta_{5} X_{3}+\beta_{7} X_{2} X_{3}
$$

Hence, the marginal effect of $X_{1}$ on $Y$ depends on the estimated coefficients as well as on the level of $X_{2}$ and $X_{3}$ for a specific cross-section and a specific point in time. If an interaction term coefficient is not significantly different from zero, it can be left out and the corresponding levels are not relevant. Based on this example, marginal effects can be calculated for all countries on our sample for a given year. The marginal effect then shows what would happen to the unemployment rate if the value of an institutional indicator changed. Consequently, a positive

\footnotetext{
${ }^{12}$ This is equivalent to what has been reported by Savin and Winker (2012) who, on the basis of Monte-Carlo simulations, identified the genetic algorithm as the superior model selection tool.
} 
marginal effect means that (de)regulation would raise (lower) unemployment. To illustrate our findings, we calculate the marginal effects for the institutional level in 2008 since this is the latest available observation. Following Greene (2002) (page 124), we calculate the standard errors for the marginal effects. This is more complex than for estimates without conditioning variables since we have to take covariances between interacting factors into account. More specifically, for the model given above, the standard error for the marginal effect of $X_{1}$ for instance, is given by

$$
\begin{aligned}
& \sigma=\sqrt{\operatorname{var}\left(\beta_{1}\right)+X_{2}^{2} \operatorname{var}\left(\beta_{4}\right)+X_{3}^{2} \operatorname{var}\left(\beta_{5}\right)+X_{2}^{2} X_{3}^{2} \operatorname{var}\left(\beta_{7}\right)+2 X_{2} \operatorname{cov}\left(\beta_{1}, \beta_{4}\right)+\ldots} \\
& \overline{\ldots 2 X_{3} \operatorname{cov}\left(\beta_{1}, \beta_{5}\right)+2 X_{2} X_{3} \operatorname{cov}\left(\beta_{4}, \beta_{5}\right)+2 X_{2}^{2} X_{3} \operatorname{cov}\left(\beta_{4}, \beta_{7}\right)+2 X_{2} X_{3}^{2} \operatorname{cov}\left(\beta_{5}, \beta_{7}\right)}
\end{aligned}
$$

This standard error provides information on the precision of the estimation of the marginal effect for given values of the conditioning factors $\left(X_{1}, X_{2}\right.$ and $X_{3}$ in the example given above). Hence, similar to the marginal effect, the standard errors depend on the country-specific institutional framework and can be calculated for each country separately. The information which is conveyed by the standard errors refers to the precision of the estimated marginal effect. A comparably low country-specific standard error indicates a low level of uncertainty surrounding the country-specific marginal effect. In contrast, high standard errors raise some doubts about the precise measurement of the marginal effect.

\subsection{Fixed effects}

The genetic algorithm identifies seven interactions as significant determinants of unemployment for the fixed effects estimator. Recall that we include the levels of the institutional variables in each model specification. Five variables are considered in at least one significant interaction term. Only the product market regulation variable does not interact with another institutional factor. This is contrary to recent evidence on a significant interdependent impact between labour and product market regulation on the labour market (Fiori et al. 2012). This unexpected finding could be the result of the particular modelling strategy which allows the comprehensive consideration of interdependencies. The interaction between product market regulation and labour market regulation in the literature could be driven by an omitted variable bias due to neglecting further relevant interactions. Alternatively, we cannot rule out that there simply has not been an interdependent relationship between labour and product market regulation for the specific country sample and time period in this study. The insignificant coefficient of product market regulation (see table 4) points in this direction. In summary, there is a conditioning effect from other institutions for a change of five institutional factors. This highlights the importance of interdependent institutional influences on the labour market and the need for considering the country-specific institutional set-up when conducting labour market reforms.

Furthermore, the appearance of higher-order interaction terms in the finally selected model 
emphasizes the complexity of the interplay of different institutional factors. This is of particular relevance for theoretical models builders who should not restrict their models to bivariate or subjectively selected interactions.

A deeper look into the results reveals that four bivariate interactions, employment protection and the net replacement rate, the net replacement rate and either labour taxes and union density, as well as bargaining coordination and union density have a relevant influence on unemployment. Furthermore, the trivariate interaction terms between, first, employment protection, labour taxes and bargaining coordination, and, second, between the net replacement rate, bargaining coordination and union density, as well as the fourfold interaction between employment protection, the net replacement rate, labour taxes and bargaining coordination appear to be important for unemployment.

The results displayed in table 2 show that especially deregulating reforms of labour taxes, product market regulation, bargaining coordination and bargaining power (approximated by union density) have the potential to reduce unemployment in the majority of countries since the majority of marginal effects of these factors are positive. Overall, lowering the taxation of labour is correlated with a reduction in unemployment in 19 countries out of 26 of the sample, while lowering the workers' bargaining power as well as increasing competition in the product market would be successful in all 26 countries. In contrast, reducing the level of employment protection and the level of unemployment benefits would have detrimental labour market effects in the majority of countries. This can at least partly explain the mixed impact of a change in employment protection and unemployment benefits on the labour market (Howell et al., 2007). The particular outcome of a change in the respective institution depends on other institutional factors. While our results suggest that increasing product market competition is beneficial for the labour market, this estimate is not significantly different from zero 13

Table 2: Marginal institutional effects (fixed effects)

\begin{tabular}{l|cccccc}
\hline & $\begin{array}{c}\text { Employ- } \\
\text { ment } \\
\text { protection }\end{array}$ & $\begin{array}{c}\text { Re- } \\
\text { place- } \\
\text { ment } \\
\text { rate }\end{array}$ & $\begin{array}{c}\text { Labour } \\
\text { taxes }\end{array}$ & $\begin{array}{c}\text { Bargain- } \\
\text { ing } \\
\text { coordina- } \\
\text { tion }\end{array}$ & $\begin{array}{c}\text { Union } \\
\text { den- } \\
\text { sity }\end{array}$ & $\begin{array}{c}\text { Product } \\
\text { market } \\
\text { regulation }\end{array}$ \\
\hline $\begin{array}{l}\text { Number of positive } \\
\text { marginal effects out of } \\
26 \text { countries }\end{array}$ & 7 & 9 & 19 & 22 & 26 & 26 \\
\hline
\end{tabular}

A positive marginal effect means that regulation (which means a higher level of the institutional indicator) is linked to a higher unemployment rate. Correspondingly, deregulation is then correlated with improved labour market performance.

In the following, we compare labour market effects through institutional changes for differ-

\footnotetext{
${ }^{13}$ It nevertheless appears in the result tables since the level of all six institutional factors are forced to be included in the selected model.
} 
ent groups of countries which are often assumed to differ in their institutional design: Scandinavian countries (Sweden, Norway, Finland, Denmark), Middle-European countries (France, Germany, Netherlands, Switzerland, Belgium, Austria), Anglo-Saxon and Asian countries (Australia, Canada, Ireland, Japan, Korea, New Zealand, United Kingdom, United States), SouthernEuropean countries (Italy, Portugal, Spain, Greece), and Eastern-European countries (Czech Republic, Hungary, Slovakia, Poland). Indeed, we find substantial differences in the estimated labour market reactions following an institutional change across groups. The groups of Southern-European, Middle-European countries and Eastern-European countries mostly show positive marginal effects. Hence, an institutional change that deregulates the institutional setup would lead to a fall in unemployment in these countries. In contrast, especially in the Anglo-Saxon and Asian, but also in the Scandinavian countries the picture is somewhat different. Here, deregulation would to a larger extent have a detrimental impact on the labour market. The following table 3 summarizes the group-specific marginal institutional impact on unemployment by showing the share of countries with positive marginal effects (decrease in the level of regulation leads to an increase in unemployment). The most heterogeneous outcome for the different groups can be observed for employment protection, unemployment benefits and labour taxes. Reducing the level of employment protection is linked to a drop especially in unemployment only in Southern-European and Middle-European countries while it has a detrimental labour market impact in all remaining groups. Concerning unemployment benefits, Eastern-European countries show a close relation between a reduction in the net replacement rate and the unemployment rate. In the other groups, the same relation is only given for a small subset of countries. Generally, the interpretation for marginal institutional effects based on interdependencies is difficult since clear theoretical predictions are not available for all institutional factors, and since interdependencies comprise up to four factors. Nevertheless, some considerations on the interaction effects are given in the following to illustrate how the same reform can produce opposing outcomes.

According to Arpaia and Mourre (2012), employment protection is particularly relevant in countries where redistribution policies are inefficiently organized and insurance against labour market risks (becoming unemployed) is therefore limited. Hence, the level of employment protection should be high in countries with a low level of unemployment benefits. However, there is a positive correlation between the level of employment protection and net replacement rates in our data sample. Countries with strict employment protection also exhibit a generous unemployment benefit system (see table 7). Yet, this could explain why reducing employment protection would be beneficial in countries with high unemployment benefits (and vice-versa). The combination of high regulation of both factors is not efficient and one of the two factors could be deregulated without generating negative labour market effects. According to our findings, the interdependent labour market effect of employment protection and unemployment benefits also depends on the labour tax system and the degree of bargaining coordination. More specifically, countries with a higher degree of bargaining coordination as well as with 
higher labour taxes are more likely to show a beneficial labour market impact through reducing employment protection. Especially bargaining coordination could work as a moderating factor.

Potential externalities of the EPL reduction are likely to be compensated through the absence of non-coordinated behaviour of either employers or employees (Baccaro and Rei, 2007). For instance, informal agreements between the employer and the worker side (what is captured in the coordination variable) could avoid that the increase in employer bargaining coordination (due to the loss in EPL strictness) transforms in increased labour transition rates, lower wages and, consequently, less labour supply.

In contrast to employment protection, reducing unemployment benefits additionally depends on the level of union density (besides the interdependency with employment protection, labour taxes and bargaining coordination). The results show that reducing net replacement rates is beneficial in countries where the level of worker bargaining power (measured by union density) is comparably low. Lower unemployment benefits increase labour supply since the outside option becomes less attractive. Since the increased labour supply is especially unemployment-reducing in countries with low union density we can assume that this effect is mainly driven by moderate wage claims through low union density.

Table 3: Share of positive marginal institutional effects: Country groups

\begin{tabular}{l|cccccc}
\hline & $\begin{array}{c}\text { Employ- } \\
\text { ment } \\
\text { protection }\end{array}$ & $\begin{array}{c}\text { Re- } \\
\text { place- } \\
\text { ment } \\
\text { rate }\end{array}$ & $\begin{array}{c}\text { Labour Bargaining } \\
\text { taxes } \\
\text { coordina- } \\
\text { tion }\end{array}$ & $\begin{array}{c}\text { Union } \\
\text { den- } \\
\text { sity }\end{array}$ & $\begin{array}{c}\text { Product } \\
\text { market } \\
\text { regulation }\end{array}$ \\
\hline Anglo-Saxon+Asian (8) & 0 & 0.25 & 0.375 & 0.75 & 1 & 1 \\
Eastern-European (4) & 0 & 1 & 0.75 & 1 & 1 & 1 \\
Southern-European (4) & 0.75 & 0.25 & 0.75 & 1 & 1 & 1 \\
Middle-European (6) & 0.67 & 0.17 & 1 & 1 & 1 & 1 \\
Scandinavian (4) & 0 & 0.25 & 1 & 0.5 & 1 & 1 \\
\hline
\end{tabular}

A positive marginal effect means that regulation (which means a higher level of the institutional indicator) is linked to a higher unemployment rate. Correspondingly, deregulation is then correlated with improved labour market performance. Each value reflects the share of positive marginal effects within a country group to the number of countries in that group. Hence, the higher the value the more likely is a positive marginal effect in that group. The number of countries in a group is given in parentheses.

Table 3 as well as the estimated marginal effects provided in table 4 suggest that institutional reforms provide the opportunity to reduce unemployment in all countries. Table 4 provides the marginal effects for 5 selected countries, one from each group, for all six institutional factors.

Concerning employment protection, an increase in the EPL indicator (ranging from 1 to 6) by one point would change unemployment by between -4.7 and 0.25 percentage points depending 
Table 4: Marginal institutional effects for selected countries

\begin{tabular}{l|cccccc}
\hline \multirow{5}{*}{ Australia } & $\begin{array}{c}\text { Employ- } \\
\text { ment } \\
\text { protection }\end{array}$ & $\begin{array}{c}\text { Replacement } \\
\text { rate }\end{array}$ & $\begin{array}{c}\text { Labour } \\
\text { taxes }\end{array}$ & $\begin{array}{c}\text { Bargaining } \\
\text { coordina- } \\
\text { tion }\end{array}$ & $\begin{array}{c}\text { Union } \\
\text { density }\end{array}$ & $\begin{array}{c}\text { Product } \\
\text { market } \\
\text { regulation }\end{array}$ \\
\hline \multirow{3}{*}{ Spain Rep. } & -4.718 & -0.078 & -0.086 & 0.191 & 0.343 & 0.110 \\
Germany & $(0.937)$ & $(0.040)$ & $(0.048)$ & $(0.308)$ & $(0.055)$ & $(0.125)$ \\
& -1.098 & 0.097 & 0.023 & 1.409 & 0.236 & 0.110 \\
Sweden & $(0.402)$ & $(0.030)$ & $(0.039)$ & $(0.264)$ & $(0.042)$ & $(0.125)$ \\
& -0.152 & -0.070 & 0.075 & 1.408 & 0.144 & 0.110 \\
& $(0.543)$ & $(0.070)$ & $(0.053)$ & $(0.325)$ & $(0.044)$ & $(0.125)$ \\
& 0.246 & -0.113 & 0.071 & 1.431 & 0.139 & 0.110 \\
& $(0.611)$ & $(0.045)$ & $(0.045)$ & $(0.289)$ & $(0.044)$ & $(0.125)$ \\
& -0.237 & -0.088 & 0.046 & -0.905 & 0.183 & 0.110 \\
& $(0.460)$ & $(0.047)$ & $(0.041)$ & $(0.318)$ & $(0.042)$ & $(0.125)$ \\
\hline
\end{tabular}

A positive marginal effect means that regulation (which means a higher level of the institutional indicator) is linked to a higher unemployment rate. Correspondingly, deregulation is then correlated with improved labour market performance. Standard errors are in parenthesis.

on the country. Besides the relevance of interdependencies with other institutional factors, this wide range might be further explained by the fact that the EPL indicator comprises of both protection for temporary and for permanent employment. Recent evidence suggests that both elements work in opposite directions (Sachs, 2012). More concretely, reductions in the regulation of flexible employment are likely to increase unemployment Cahuc and Postel-Vinay, 2002; Blanchard and Landier, 2002). If changes in employment protection have been mainly driven by changes of the regulation of flexible employment in the sample period, the negative marginal effects are not surprising.

A reduction in the net replacement rate by 1 percentage point would be related to an unemployment rate which is 0.1 percentage points lower in the Czech Republic, and around 0.1 percentage points higher in Australia, Sweden, Germany and Spain. In contrast, reducing labour taxes by one percentage point corresponds to higher unemployment in Australia $(+0.08$ percentage points), and to lower unemployment in the remaining four countries (-0.02 and 0.08 percentage points). While these effects are rather small in economic terms, changing the bargaining power (proxied by the union density) shows larger effects. A reduction in the union density by 1 percentage point is linked to a reduction in the unemployment rate between 0.14 and 0.34 percentage points. Since product market regulation does not interact with other institutional factors in our sample the effect on unemployment is identical for all countries. A rise in competition (a fall of the indicator value by one point) due to, for instance, decreased bureaucracy costs or a reduction in price controls leads to a reduction in unemployment by 0.1 percentage points. Finally, reducing bargaining coordination was successful in four of the five 
countries. A one point drop in the indicator value is related to a reduction in unemployment between 0.19 and 1.43 percentage points. Concerning the preciseness of the estimated marginal effects, the standard errors are comparably high especially for labour taxes and employment protection for all five countries, and for bargaining coordination for Spain and bargaining coordination for Australia. The remaining institutional marginal effects are estimated with high precision.

The effects are substantial for some reform components and for some countries. Nevertheless, especially the marginal effects of changes in employment protection and bargaining coordination should be interpreted with caution. Both indicators are rather crude measures. For the remaining institutional variables, the marginal effects provide a reasonable approximation for potential changes in unemployment following a labour market reform.

\subsection{GMM}

The fixed effects estimates could be biased due to the correlation of the lagged dependent variable with the error term through the country-specific fixed effects. We therefore run the genetic algorithm with the theoretically preferred system GMM estimator. Overall, the findings are similar to the results produced with the fixed effects estimator. Still, seven interactions terms are identified as relevant for explaining unemployment. However, the interactions between employment protection and unemployment benefits as well as between unemployment benefits and labour taxes are not selected within the GMM estimation. In contrast, the interactions between employment protection and labour taxes as well as between employment protection, unemployment benefits and labour taxes are chosen through the genetic algorithm. This change in the selected model results in a slightly different pattern of positive marginal effects across countries. The number of positive marginal effects, illustrated in the following table, increases for employment protection from seven to 14, and for labour taxes from 19 to 20, while it decreases for unemployment benefits from nine to eight. The remaining numbers do not change. The superiority of the GMM over the fixed effects estimator, however, hinges essentially on assumptions which can be tested (see chapter 3 for a brief discussion). Unfortunately, already the Sargan test for overidentifying restrictions of the first-step estimator performs rather dubious since the p-value of this test equals 1 for virtually all models. This is a well-documented shortcoming of the Hansen test (which is a more general form of the Sargan test based on the estimated variances of the first-step estimation) in case of instrument proliferation. For the Hansen test, reducing the set of instruments could alleviate the problem. However, this should not be the case for the Sargan test. Estimating the second-step GMM estimator with a collapsed instrument set and applying the Hansen test which is, in contrast to the Sargan test, robust to heteroskedasticity would be a reasonable solution. We run the system GMM estimation with a collapsed instrument set following Roodman (2009). As expected, the Hansen test performs poorly and the findings are unstable. As already stated, the second-step weighting 
Table 5: Marginal institutional effects (GMM)

\begin{tabular}{l|cccccc}
\hline & $\begin{array}{c}\text { Employ- } \\
\text { ment } \\
\text { protection }\end{array}$ & $\begin{array}{c}\text { Re- } \\
\text { place- } \\
\text { ment } \\
\text { rate }\end{array}$ & $\begin{array}{c}\text { Labour } \\
\text { taxes }\end{array}$ & $\begin{array}{c}\text { Bargain- } \\
\text { ing } \\
\text { coordina- } \\
\text { tion }\end{array}$ & $\begin{array}{c}\text { Union } \\
\text { den- } \\
\text { sity }\end{array}$ & $\begin{array}{c}\text { Product } \\
\text { market } \\
\text { regulation }\end{array}$ \\
\hline $\begin{array}{l}\text { Number of positive } \\
\text { marginal effects out of } \\
26 \text { countries }\end{array}$ & 14 & 8 & 20 & 22 & 26 & 26 \\
\hline
\end{tabular}

A positive marginal effect means that regulation (which means a higher level of the institutional indicator) is linked to a higher unemployment rate. Correspondingly, deregulation is then correlated with improved labour market performance.

matrix seems to be poorly identified which results in these unstable second-step estimates. We therefore have to assume that the selected instruments are invalid, and that the system GMM estimator does not provide reliable results for our model structure. Therefore, we trust the fixed effects findings more. As a consequence, we accept the consequences of the potential Nickell bias due to the dynamic structure of our model.

\subsection{The role of gender}

Up to now, we have focused on the aggregate unemployment rate as our variable of interest. Nevertheless, recent research (Bertola et al., 2007, Di Tella and MacCulloch, 2005), for instance) suggests that institutional changes affect distinct groups differently, depending on the respective labour supply elasticities. Consequently, we expect that different models are selected once we distinguish between the unemployment rates of males and females. According to Bertola et al. (2007), we suppose that female employment react stronger to changes in the institutional environment due to a more elastic labour supply. More specifically, the theoretical model of Bertola et al. (2007) predicts that female employment reduces more than male employment when stronger unions demand higher wages caused by the steeper labour supply function of females. Hence, we assume that institutional changes which make the labour market more flexible should reduce female employment more than male employment. In order to determine the impact on unemployment, however, one has to take into account that unemployed might leave the labour market and move into inactivity. A reduction in employment is not necessarily related to an increase in unemployment as long as the new unemployed leave the labour market. We assume that movements into inactivity are negligible, and that the drop in employment translates into an increase in unemployment. This might likely be larger for female than for male employees through flexibilisation. Consequently, we expect that the number of positive marginal effects is larger for female than for male unemployment for all six indicators.

The following figure 1 gives an overview on the different marginal institutional effects for 
Figure 1: Number of positive marginal effects in 26 countries separated by gender

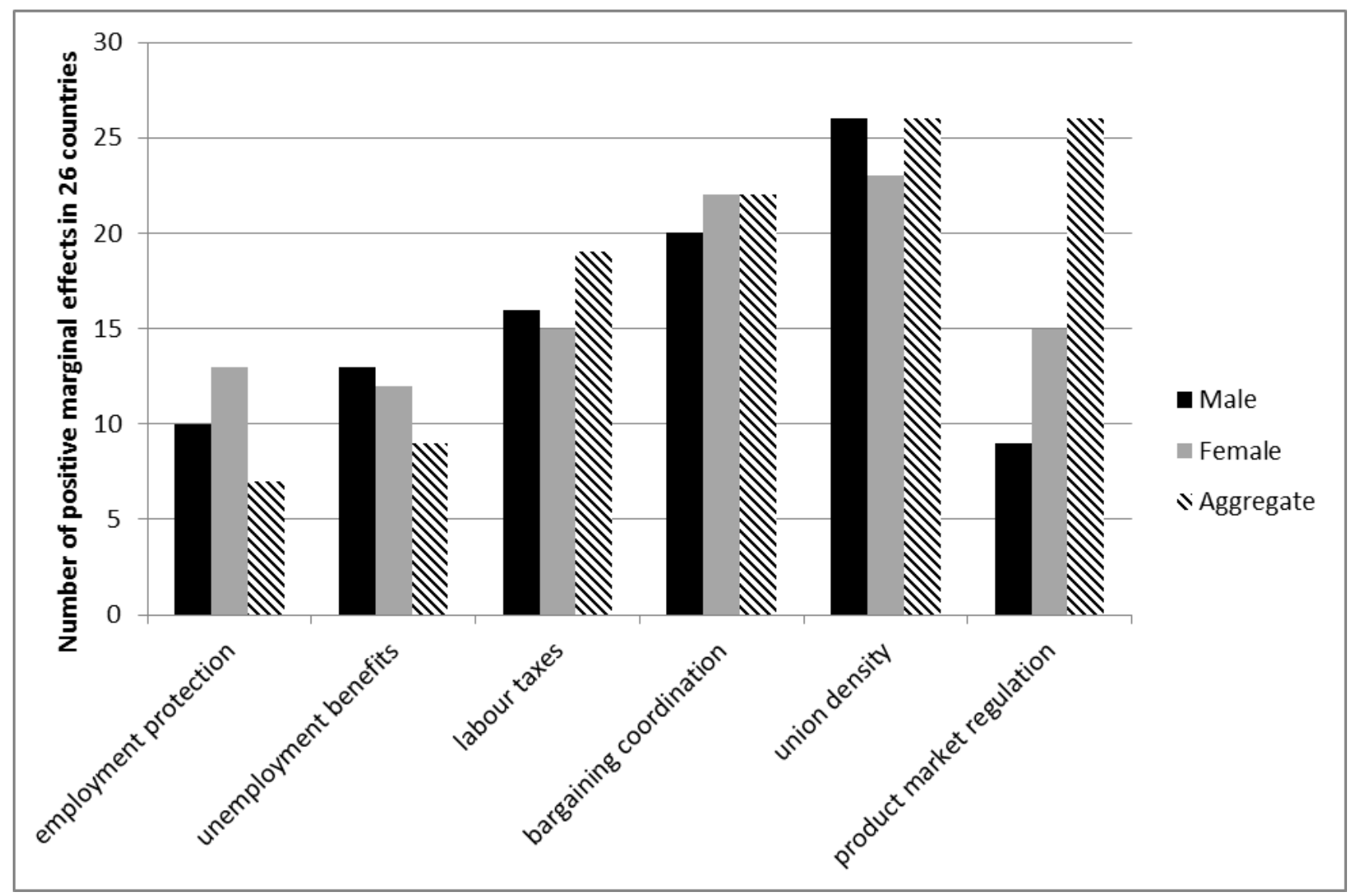

the unemployment rates of males and females, and for the aggregate unemployment rate. Overall, our hypothesis that there are more positive marginal effects for female unemployment only holds for employment protection, bargaining coordination, and for product market regulation. For unemployment benefits, labour taxes and union density, the positive marginal effects prevail for male unemployment. The largest difference between male and female unemployment can be documented for product market regulation. Female unemployed would benefit from a deregulation in this category in 15 countries, while it would be 9 for male unemployment.

Similar to the aggregate unemployment rate, reductions in the level of regulation of labour taxes, bargaining coordination, and union density would be successful in the majority of countries. The impact of deregulations of employment protection as well as unemployment benefits is less clear, it heavily depends on the country-specific institutional framework. The findings for product market regulation are somewhat surprising since the impact of an increase in competition is homogeneously beneficial for aggregate unemployment. This is partly due to the fact that product market regulation appears as a significant interaction partner in the models for gender-specific unemployment. 


\section{Conclusion}

This paper analyses the impact of interdependencies between institutional factors for the evolution of unemployment. Based on an innovative model selection approach, which is combined with a classical dynamic fixed-effect estimator for a two-way error component model, higherorder institutional interdependencies are identified for a panel of 26 countries ranging from 2001 to 2008. Thereby, we apply a genetic algorithm being a heuristic optimization method which has not been used within the unemployment-institution literature. In contrast to the previous literature, this paper is the first to focus on the impact of higher-order institutional interactions on unemployment and one of the first to consider a dynamic model specification in the context of institutional interactions. It thereby allows for a more precise and detailed analysis of the impact of interdependencies between different labour market institutions on labour market performance on a cross-country level.

The results suggest that there are substantial differences across countries in the labour market impact of institutional changes for nearly all selected institutional indicators. Hence, the impact of a reform of employment protection, unemployment benefits, labour taxes, bargaining power, and bargaining coordination crucially depends on the country-specific institutional setting.

Especially, reductions in labour taxes, bargaining power, product market regulation, and bargaining coordination seem to be unemployment-reducing in the majority of countries. In contrast, lowering employment protection and unemployment benefits are much less likely to have the trivially expected consequences that deregulation is the road to success, although such reforms would be beneficial in some countries.

It further stands out that five of the six institutional categories matter as conditioning factors. This is particularly relevant for theoretical models by providing, first, empirical evidence that institutions are linked in a more sophisticated way than considered before, and, second, empirical guidance which institutional factors should be considered in such interdependencies.

We further document that institutional changes have a heterogeneous impact on the male and female unemployed. According to theory we expected that institutions positive marginal effects in the majority of countries, especially compared to male unemployment. Indeed, we confirm this hypothesis for three institutional factors; employment protection, bargaining coordination, and product market regulation. However, we find a larger number of positive marginal effects for unemployment benefits, labour taxes and bargaining coordination for male unemployment. Hence, we document that institutional changes show a heterogeneous impact not only across countries, but also across gender. Yet, the model setup with a specific set of interactions has only limited power to explicitly identify the drivers for the distinct marginal institutional effects for male and female unemployment.

Note that the findings should be interpreted with caution. Due to the lack of adequate 
instruments and the inability of the system GMM estimator to provide reliable results, no causal relationship between institutions and unemployment can be set up. Furthermore, while the selection of institutional factors is derived directly from theory, additional institutional factors like active labour market policies or family policies might influence the findings. Nevertheless, the findings provide robust evidence that (i) interdependencies are crucial for the labour market effect of an institutional reform (ii) the order of interactions is rather high since five of six considered factors are involved in relevant interaction terms and (iii) reform recommendations should not be based on success stories from specific countries, but on an accurate evaluation of the country-specific institutional setting.

While the findings provide reliable qualitative evidence on the role of institutional interactions, improvements in data coverage and quality could pave the way to a more profound quantitative analysis of conditional institutional effects on the labour market. 


\section{References}

Acosta-González, Eduardo and Fernando Fernández-Rodríguez, "Model selection via genetic algorithms illustrated with cross-country growth data," Empirical Economics, 2007, 33 (2), 313-337.

Amable, Bruno, Lilas Demmou, and Donatella Gatti, "The effect of employment protection and product market regulation on labour market performance: substitution or complementarity?," Applied Economics, 2011, 43 (4), 449-464.

Andersen, Torben and Michael Svarer, "Flexicurity - Labour Market Performance in Denmark," CESifo Working Paper Series 2108, CESifo Group Munich 2007.

Arellano, Manuel and Stephen Bond, "Some Tests of Specification for Panel Data: Monte Carlo Evidence and an Application to Employment Equations," Review of Economic Studies, 1991, $58(2), 277-97$.

Arpaia, Alfonso and Gilles Mourre, "Institutions And Performance In European Labour Markets: Taking A Fresh Look At Evidence," Journal of Economic Surveys, 2012, 26 (1), $1-41$.

Baccaro, Lucio and Diego Rei, "Institutional Determinants of Unemployment in OECD Countries: Does the Deregulatory View Hold Water?," International Organization, 2007, 61 (03), 527-569.

Bai, Jushan and Serena Ng, "Confidence Intervals for Diffusion Index Forecasts and Inference for Factor-Augmented Regressions," Econometrica, 2006, 74 (4), 1133-1150.

Baltagi, Badi H., Economic Analysis of Panel Data, 3. ed., Wiley, 2003.

Bassanini, Andrea and Romain Duval, "Unemployment, institutions, and reform complementarities: re-assessing the aggregate evidence for OECD countries," Oxford Review of Economic Policy, 2009, 25 (1), 40-59.

Belot, Michèle and Jan C. van Ours, "Does the recent success of some OECD countries in lowering their unemployment rates lie in the clever design of their labor market reforms?," Oxford Economic Papers, 2004, 56 (4), 621-642.

Bertola, Giuseppe, Francine Blau, and Lawrence Kahn, "Labor market institutions and demographic employment patterns," Journal of Population Economics, 2007, 20 (4), 833-867.

Blanchard, Olivier and Augustin Landier, "The Perverse Effects of Partial Labour Market Reform: fixed-Term Contracts in France," Economic Journal, 2002, 112 (480), F214-F244. 
- and Justin Wolfers, "The Role of Shocks and Institutions in the Rise of European Unemployment: The Aggregate Evidence," Economic Journal, 2000, 110 (462), C1-33.

Blundell, Richard and Stephen Bond, "Initial conditions and moment restrictions in dynamic panel data models," Journal of Econometrics, 1998, 87 (1), 115-143.

_ and _ , "GMM Estimation with persistent panel data: an application to production functions," Econometric Reviews, 2000, 19 (3), 321-340.

Born, Benjamin and Jörg Breitung, "Testing for Serial Correlation in Fixed-Effects Panel Data Models," mimeo, 2013.

Brambor, Thomas, William Clark, and Matt Golder, "Understanding Interaction Models: Improving Empirical Analyses," Political Analysis, 2006, 14, 63-82.

Braumoeller, Bear F., "Hypothesis Testing and Multiplicative Interaction Terms," International Organization, 2004, 58 (04), 807-820.

Bun, Maurice J. G. and Frank Windmeijer, "The weak instrument problem of the system GMM estimator in dynamic panel data models," Econometrics Journal, 2010, 13 (1), 95-126.

Cahuc, Pierre and Fabien Postel-Vinay, "Temporary jobs, employment protection and labor market performance," Labour Economics, 2002, 9 (1), 63-91.

Coe, David T. and Dennis J. Snower, "Policy Complementarities: The Case for Fundamental Labor Market Reform," IMF Staff Papers, 1997, 44 (1), 1-35.

Di Tella, Rafael and Robert MacCulloch, "The consequences of labor market flexibility: Panel evidence based on survey data," European Economic Review, 2005, 49 (5), 1225-1259.

Elmeskov, Jørgen, John Martin, and Stefano Scarpetta, "Key lessons for labour market reforms: evidence from OECD countries' experiences," Swedish Economic Policy Review, 1998, 5, 205-252.

Fernandez, Carmen, Eduardo Ley, and Mark F. J. Steel, "Benchmark priors for Bayesian model averaging," Journal of Econometrics, 2001, 100 (2), 381-427.

Fiori, Giuseppe, Giuseppe Nicoletti, Stefano Scarpetta, and Fabio Schiantarelli, "Employment Effects of Product and Labour Market Reforms: Are There Synergies?," Economic Journal, 2012, 122 (558), F79-F104.

Gatu, Cristian, Erricos J. Kontoghiorghes, Manfred Gilli, and Peter Winker, "An efficient branch-and-bound strategy for subset vector autoregressive model selection," Journal of Economic Dynamics and Control, 2008, 32 (6), 1949-1963.

Greene, William H., Economic Analysis, 5. ed., Prentice Hall, 2002. 
Gwartney, James, Robert Lwason, and Joshua Hall, "Economic Freedom of the World 2012 Annual Report," Technical Report, Fraser Institute 2012.

Hendry, David F. and Hans-Martin Krolzig, "We Ran One Regression," Oxford Bulletin of Economics and Statistics, 2004, 66 (5), 799-810.

Hoover, Kevin D. and Stephen J. Perez, "Truth and Robustness in Cross-country Growth Regressions," Oxford Bulletin of Economics and Statistics, 2004, 66 (5), 765-798.

Howell, David R. and Miriam Rehm, "Unemployment compensation and high European unemployment: a reassessment with new benefit indicators," Oxford Review of Economic Policy, 2009, 25 (1), 60-93.

_, Dean Baker, Andrew Glyn, and John Schmitt, "Are Protective Labor Market Institutions at the Root of Unemployment? A Critical Review of the Evidence," Capitalism and Society, 2007, 2 (1), 1-73.

IMF, "World Economic Outlook," Technical Report 2003.

Kapetanios, George, "Variable selection in regression models using nonstandard optimisation of information criteria," Computational Statistics \& Data Analysis, 2007, 52 (1), 4-15.

Krolzig, Hans-Martin and David F. Hendry, "Computer automation of general-to-specific model selection procedures," Journal of Economic Dynamics and Control, 2001, 25 (6-7), 831-866.

Leamer, Edward E., "Let's Take the Con Out of Econometrics," American Economic Review, 1983, 73 (1), 31-43.

Nickell, Stephen and Richard Layard, "Labor market institutions and economic performance," in O. Ashenfelter and D. Card, eds., Handbook of Labor Economics, Vol. 3 of Handbook of Labor Economics, Elsevier, 1999, chapter 46, pp. 3029-3084.

_ , Luca Nunziata, and Wolfgang Ochel, "Unemployment in the OECD Since the 1960s. What Do We Know?," Economic Journal, 2005, 115 (500), 1-27.

OECD, "Evidence and Explanations, Part II - The Adjustment Potential of the Labour Market," Technical Report, OECD Job Study 1994.

Perez-Amaral, Teodosio, Giampiero M. Gallo, and Halbert White, "A Flexible Tool for Model Building: the Relevant Transformation of the Inputs Network Approach (RETINA)," Oxford Bulletin of Economics and Statistics, 2003, 65 (s1), 821-838.

Roodman, David, "A Note on the Theme of Too Many Instruments," Oxford Bulletin of Economics and Statistics, 2009, 71 (1), 135-158. 
Sachs, Andreas, "Institutions and unemployment: Do interactions matter?," ZEW Discussion Papers 11-057, ZEW - Zentrum für Europäische Wirtschaftsforschung / Center for European Economic Research 2011.

_, "What really drives unemployment? A bayesian approach to determine the impact of institutions on the unemployment rate," Economics Bulletin, 2012, 32 (1), 1008-1019.

Sala-I-Martin, Xavier, "I Just Ran Two Million Regressions," American Economic Review, 1997, 87 (2), 178-83.

Savin, Ivan and Peter Winker, "Heuristic Optimization Methods for Dynamic Panel Data Model Selection: Application on the Russian Innovative Performance," Computational Economics, 2012, 39 (4), 337-363.

Scarpetta, Stefano, "Assessing the Role of Labour Market Policies and Institutional Settings of Unemployment: A Cross-Country Study," Technical Report 26, OECD Economic Studies 1996.

Soskice, David, "Wage Determination: The Changing Role of Institutions in Advanced Industrialized Countries," Oxford Review of Economic Policy, 1990, 6 (4), 36-61.

Visser, Jelle, "The ICTWSS Database: Database on Institutional Characteristics of Trade Unions, Wage Setting, State Intervention and Social Pacts 1960-2010 (ICTWSS)," Technical Report, Amsterdam Institute for Advanced Labour Studies AIAS 2011.

Winker, Peter, "Identification of multivariate AR-models by threshold accepting," Computational Statistics \& Data Analysis, 1995, 20 (3), 295-307.

_ , "Optimized Multivariate Lag Structure Selection," Computational Economics, 2000, 16 $(1 / 2), 87-103$.

- and Dietmar Maringer, "Optimal lag structure selection in VAR and VEC models," in A. Welfe, ed., New Directions in Macromodelling : Essays in Honor of J. Michael Finger, Elsevier, 2006, pp. 213-234.

- and Kai-Tai Fang, "Application of Threshold-Accepting to the Evaluation of the Discrepancy of a Set of Points," SIAM Journal of Numerical Analysis, 1997, 34, 2028-2042. 


\section{Annex}

Threshold Accepting (TA): The model structure is initialized randomly with a binary string of zero and ones $\left(\varphi^{0}\right)$. Based on the randomly initialized model structure, the estimation is performed and our objective function is calculated. This value and the model structure are stored. After the initialization, the iterations start. In each iteration step a new solution $\left(\varphi^{1}\right)$ which is a neighbour to the current solution is derived. Two regressors out of all potential regressors are selected randomly. The following rule applies: The first regressor is included if it was excluded before and the second vice versa. This corresponds to a Hamming Distance of two. Based on this new structure, the new information criterion is calculated. Then, the difference of the previous and the new value of the loss function is calculated. If the difference is smaller than the corresponding value of the threshold sequence $(\tau)$ the new structure is accepted else the previous combination is restored. We use a data-driven threshold sequence as advocated by Winker and Fang (1997) which is based on differences of the objective function. These are generated by running the algorithm without the acceptance criterion and taking the difference of the initial value and new objective function. The threshold sequence for the threshold accepting algorithm gets linearly lowered to zero within $60 \%$ as recommended by Savin and Winker (2012). In each iteration step the elitist is preserved to account for potential impairments of the objective function. The next iteration step follows until the predefined number of iterations $\left(I_{\max }\right)$ is done.

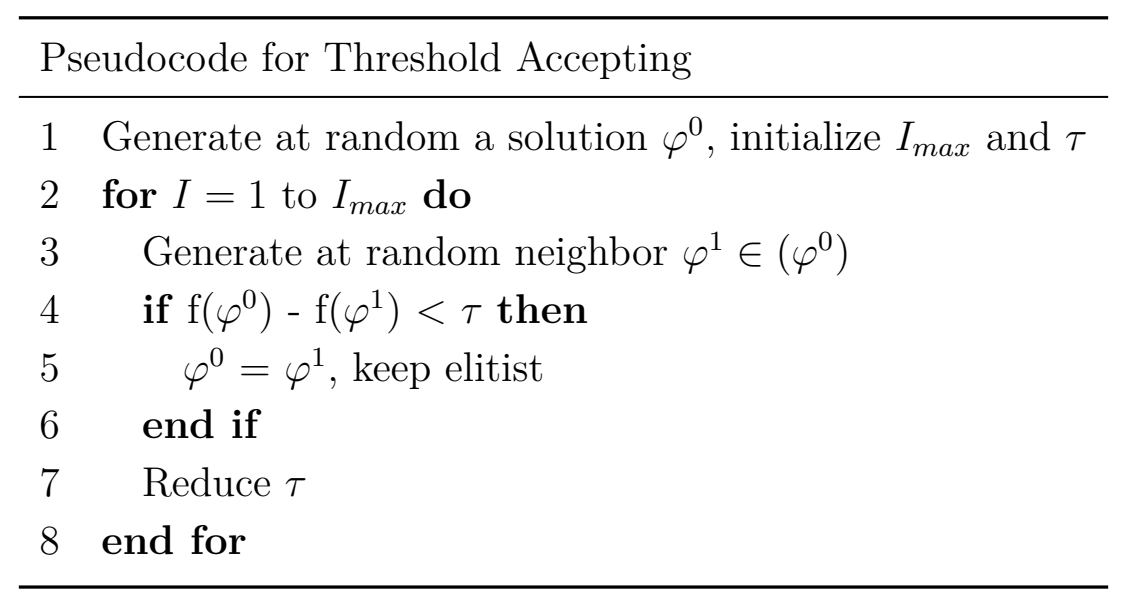


Table 6: Data summary statistics

\begin{tabular}{l|cccc}
\hline & Median & Minimum & Maximum & S.D. \\
\hline Unemployment rate & 6.08 & 2.53 & 19.98 & 3.46 \\
Employment protection & 1.90 & 0.21 & 3.67 & 0.77 \\
Net replacement rate & 0.73 & 0.55 & 0.86 & 0.08 \\
Labour taxes & 0.35 & 0.10 & 0.49 & 0.10 \\
Bargaining coordination & 3.00 & 1.00 & 5.00 & 1.21 \\
Union density & 0.22 & 0.08 & 0.78 & 0.19 \\
Product market regulation & -6.60 & -10 & -4.10 & 0.89 \\
Real exchange rate & 0.00 & -14.10 & 24.51 & 2.91 \\
Productivity & 4.83 & 4.51 & 5.01 & 0.11 \\
Trade balance & -0.02 & -73.69 & 22.54 & 11.88 \\
Output Gap & 1.10 & -4.54 & 9.00 & 2.35 \\
\hline
\end{tabular}

Table 7: Correlation coefficients between institutions

\begin{tabular}{l|cccccc}
\hline & EPL & NRR & TAX & COO & UDE & PMR \\
\hline Employment protection (EPL) & 1.00 & 0.37 & 0.50 & 0.42 & 0.06 & 0.32 \\
Net replacement rate (NRR) & & 1.00 & 0.21 & 0.38 & 0.36 & -0.09 \\
Labour taxes (TAX) & & & 1.00 & 0.23 & 0.33 & 0.24 \\
Bargaining coordination (BCO) & & & & 1.00 & 0.37 & -0.02 \\
Union density (UDE) & & & & & 1.00 & -0.38 \\
Product market regulation (PMR) & & & & & & 1.00 \\
\hline
\end{tabular}

